\title{
CHANGES TO DISASTER INSURANCE IN NEW ZEALAND
}

\begin{abstract}
SUMMARY
This article is based on material supplied by EQC in its information kit detailing the background to and consequences of the Earthquake Act 1993. After discussing the need for a change in insuring for disasters, the new natural disaster insurance for residential properties - EQCover - is outlined. This is followed by an outline of the phase-out of EQC cover for disaster insurance for commercial and "Special Purpose" properties. The new structure for and role of the Earthquake Commission is also outlined.
\end{abstract}

\section{INTRODUCTION}

Recently, Parliament passed the Earthquake Commission Act 1993 which will take effect from 1 January 1994 . The main points of this legislation are that disaster insurance cover now called EQCover - will cover only residential property and this will insure dweelings for replacement value rather than the indemnity value. This paper explains why the Earthquake and War Damage Commission (EQC) was set up back in 1945, what has happened since that time, and why changes are now being made to New Zealand's natural disaster insurance system.

\section{The ring of fire}

New Zealand gets more than its share of earthquake and volcanic activity. The North and South Islands lie directly on that vast circle of volcanic activity around the Pacific Ocean which is sometimes called the Ring of Fire. Most of the world's earthquake energy is released along the Ring of Fire.

Part of the boundaries of two of the huge tectonic plates that make up the earth's surface run along the length of New Zealand. These two plates - the Pacific Plate and the Indo-Australian Plate - slide under and past each other. In consequence New Zealand is etched with fault lines. Most of the active faults are found between East Cape and North Canterbury to the east of the country, and between Taranaki and Westport to the west. Fiordland is another significant earthquake zone.

New Zealand is also subject to significant volcanic and hydrothermal activity in New Zealand. Both Auckland and Rotorua, for example, are situated near volcanic centres.

\section{Origin of EQC}

The Earthquake and War Damage Commission was set up in 1945 under the Earthquake and War Damage Act 1944.

Before 1945, earthquake insurance on residential and commercial premises was voluntary, although war insurance was compulsory. In practice, few people took out earthquake insurance. Parliament decided that a compulsory scheme was necessary to ensure equity by making sure everyone contributed to the Fund and everyone was protected. Another purpose behind setting up the EQC was to ensure faster recovery from major disasters. When the Act was being debated, two years after the 1942 Wairarapa earthquake, many of the wrecked and uninsured buildings there hadn't even been cleared away, let alone rebuilt.

Since its establishment, the EQC has been called on to pay out on claims relating to several moderately severe events, such as the 1968 Inangahua earthquake, the 1987 Bay of Plenty earthquake, and the Abbotsford landslip, and on many claims arising from milder earthquakes.

\section{Why change the old system?}

EQC maintains a large fund and has considerable reinsurance in place to cover, as much as possible, the insurance costs associated with earthquakes and certain other disasters in New Zealand. In the event that a disaster or disasters uses up the EQC's funds and reinsurance, the Government is legally obliged to pick up the over-run costs.

The potential costs of the Government liability associated with disasters in New Zealand is very large. This is beyond the Government's liability to meet other costs that may be associated with a major disaster, e.g. social welfare payments and the restoration of government facilities.

For some time, successive Governments have been working towards reducing this contingent liability.

We have also seen increasing resentment in recent years from commercial property owners to the current compulsory aspects of disaster insurance. This has, on several occasions, led to litigation between EQC and some commercial property owners. Clearly, many property owners would like to make their own disaster insurance arrangements.

Also, the prevailing attitude to the role of Government has changed in recent years. When the original Act was passed in 1944, the generally accepted belief was that Government can and should be involved in every aspect of the economy. Now the attitude is that the Government has a more limited role, only stepping in to do things that can't be done through free markets.

Since the 1944 Act the insurance industry itself has changed its approach to householder insurance policies. These developments have made many of the provisions of the old Act outmoded. In particular:

EQC's current insurance cover is based on indemnity values (present value, allowing for age and likely remaining useful life); this is out of step with modern insurance policies, including those for non-residential 
property, which are generally based on replacement values;

few insurance policies now contain a condition called "average", a provision penalising policy-holders for not insuring property to its full value.

As well, the EQC's old controlling Act, and the set of ideas and policies that underlie it, are nearly 50 years old. It has not been properly reviewed until very recently, and there had been an accretion of regulations and judicial decisions over the five decades that made the law increasingly complex and inaccessible to non-lawyers.

\section{Consultation and Discussion Papers}

A Public Discussion Paper on Earthquake Insurance was prepared in 1991, as a basis for consultation. The 1991 Paper put the issue in these terms:

the Government's principle aim in relation to natural disasters must be to reduce distress, both in those immediately affected by the disaster and in the New Zealand economy and society;

- State resources would inevitably be limited in dealing with the aftermath of a major natural disaster; therefore the priority must be humanitarian areas like the provision of housing and other basic amenities as well as the infrastructure, rather than towards industry;

the Government should complement, not replace, the actions of private parties in making their own insurance arrangements.

The Government consulted with the bodies who would be most affected by change, including property managers and the insurance industry.

The new Earthquake Commission Act 1993 arose from the discussion document and the related consultation.

The following sections explain the changes to earthquake and disaster insurance for residential, commercial "special purpose" properties, and to the EQC itself, in more detail.

\section{EQCOVER: NATURAL DISASTER INSURANCE AND RESIDENTIAL PROPERTY}

EQCover is the new disaster insurance cover which will be offered by EQC from 1 January 1994 . It will cover residential property and some residential land. Full details are available in the Earthquake Commission Act, recently passed by Parliament.

EQCover will insure dwellings for replacement value and, as well, will be able to cover personal effects for their replacement value, up to the smallest of the following:

- The amount insured for in a replacement basis houseowner's fire insurance policy;

A lesser amount specified as the limit for EQCover, if there is no replacement policy, with an amount insured on it in the fire policy;

$\$ 100,000(+$ GST) for a dwelling, $\$ 20,000(+$ GST) for personal property.

These limits, or "caps", can only be changed by Act of Parliament. If more cover is needed (noting that the
$\$ 100,000$ cap is for the dwelling only, and does not include the land) "top-up" insurance from private insurance companies should be available.

Retaining walls will continue to be covered on an "indemnity value" basis.

Personal property will be insured on the same terms as they are in a household insurance policy. If insurance cover on personal property is for indemnity value only, then EQCover will do the same. Personal property includes personal effects, domestic home contents, etc.

\section{Differences from old scheme}

EQC insurance is at present on the basis of indemnity value, which takes into account the age of the insured building or property, and which is generally below replacement value. Replacement value will offer homeowners and their families better and more realistic protection.

The present indemnity-based cover represents a form of "cap". Now the new "caps" are to be explicitly spelled out.

Also, with the new system "average" will no longer apply. That means there will no longer be a penalty for insuring a house or its contents for less than its full value.

\section{What about apartments and "granny flats"?}

Some premises contain more than one "dwelling". Apartment buildings, large houses that have been divided into flats, and houses with self-contained "granny flats" are - examples. In those cases, owners will be able to insure up to as many "caps" as there are self-contained dwellings within the single premises. They must alert their insurance company to this, however, otherwise the one cap will apply to the entire premises.

\section{Difference from old scheme}

This is a new provision.

\section{What are these "caps"?}

The introduction of "caps", or maximum payments, under EQCover, means that some homeowners will want to have top-up insurance in place, just as many people presently have a different sort of top-up cover to make up the difference between indemnity and replacement value.

People with homes with a replacement value of more than $\$ 100,000$ will need to acquire insurance beyond EQCover, if they want full protection.

It is expected that private insurers' premium for top-up cover will be at a lower rate than the premium for full cover (above indemnity) applicable under current rules. This is because the combination maximum of $\$ 100,000+$ GST for home and $\$ 20,000+$ GST for personal property available for replacement costs under EQCover will, effectively, operate as the "excess" in private insurers' top-up policies i.e. insurance companies will only have to pay out for claims in excess of these amounts. 
It is useful to note, however, that EQC's own records show that the vast majority of claims in recent years have come in under the $\$ 100,000$ and $\$ 20,000$ caps. Earthquakes tend to damage, rather than totally destroy, property.

Ultimately, people will have to assess for themselves the risks involved and the worth of insurance beyond EQCover. Certainly, the most prudent of homeowners with a home with a replacement value significantly in excess of $\$ 100,000$ will be seeking top-up insurance.

\section{Difference from old scheme}

Replacement, not indemnity, value will be used when determining payments on claims, up to the $\$ 100,000$ and $\$ 20,000$ limits. Under the current scheme, the indemnity basis means there is usually a significant difference between the cover provided by EQC and the full cost of replacing or repaining items destroyed or damaged.

\section{What sort of property will be insured by EQCover?}

\section{EQCover will insure:}

- dwellings (self-contained premises used as a home);

- personal property: personal belongings in (or temporarily removed from) the dwelling, except property used for commercial purposes;

- the land immediately round the dwelling.

Land cover includes underground services owned by the homeowner, and land within 8 metres around the dwelling. Main accessways will still be covered up to 60 metres.

\section{Differences from old scheme}

$E Q C$ will no longer insure motor vehicles, trailers or boats; nor will it insure jewellery, money, documents or securities, or works of art.

Important: $E Q C$ will be withdrawing from coverage of non-residential, including commercial, property.

\section{What about the cost of EQCover?}

The cost of EQCover will be 5 cents a year for every $\$ 100$ of property insured. The most a homeowner will pay in a year will be $\$ 67.50$ (GST included), for one dwelling and the personal property it contains.

\section{Difference from old scheme}

Nothing. In fact EQC has not changed this rate since 1944.

\section{Will EQCover be compulsory with fire insurance?}

If fire insurance is bought, a homeowner must also take out EQCover. EQCover will only be compulsory when fire insurance is taken out. (Standard houseowner's or house and contents insurance policies include fire insurance, along with some other risks.)

\section{Difference from old scheme}

Nothing. These rules will not change.

\section{How will EQCover be bought?}

EQCover will be acquired automatically when insurance on a house or personal property is bought. A homeowner will not deal directly with EQC, but through his/her insurance company. When fire insurance is bought, the insurance company will pass on to the EQC the proportion of payment that covers EQCover.

\section{Difference from old scheme}

Nothing. These rules will not change.

\section{What kinds of disasters will EOCover insure against?}

EQCover will insure residential property against loss or damage caused by "natural disaster", that is:

- earthquake, natural landslip, volcanic eruption, hydrothermal activity or tsunami (tidal wave);

- in the case of residential land, a storm or flood;

fire caused by any of these.

As at present, EQCover will not cover dwellings, their contents, and other personal property, against storms and floods, or any sort of property against subsidence and erosion.

\section{Differences from old scheme}

War damage will no longer be covered.

Also, previously $E Q C$ insured only against fire caused by earthquakes; it has widened this to include fire caused by the other natural disasters covered by $E Q C$.

\section{What about "averagen?}

Another significant change has to do with the concept of "average". For example under the current scheme, if a home is insured for $80 \%$ of its value, then EQC need pay out only $80 \%$ of any claim. This works as a penalty against those who underinsure their home. From 1 January 1994, "average" will not apply to residential property.

\section{What about excess?}

Excess is the amount deducted from an insurance claim before payment is made. Imposing an excess is considered fair and reasonable for the following reasons:

- keeps premiums down;

- recognises the cost of handling claims

- ensures people carry a small part of the responsibility themselves.

The following table shows how excess will be calculated with EQCover:

Table: Excess rates under EQCover

$\begin{array}{lcll} & \text { Per cent } & \$ \text { minimum excess } & \$ \text { maximum excess } \\ \text { Dwelling: } & 1 \% & \$ 200 & \$ 1,000 \\ \text { Personal effects: - } & \$ 200 & \$ 200 \\ \text { Land: } & 10 \% & \$ 500 \text { per dwelling } & \$ 5,000 \text { per claim }\end{array}$


Note that if there is a combined claim for both house and personal effects, EQC will apply only one minimum excess.

\section{Difference from old scheme}

The excess on land will remain the same. However, the excess on dwellings and personal property will increase from 1 per cent to 2 per cent, and from $\$ 200$ to $\$ 500$.

\section{What about making a claim under EQCover?}

A claim under EQCover policy will be able to be made by contacting EQC by letter or phone within 30 days of the "event", although in extraordinary individual cases this may be extended up to 3 months. For a major disaster, EQC will make special arrangements for claims reporting, possibly working with local insurance company people. Details will be broadcast on radio and television, and published in the newspapers.

Unless a claim is minor, EQC will arrange for an assessor to come and inspect the damage and advise EQC on how much should be paid to settle the claim fairly.

EQC will settle claims by meeting the cost of "making good" damage by repair or replacement. EQC is not bound to replace or reinstate damaged property exactly, only as far as reasonably possible and in a reasonably sufficient manner.

\section{What is different?}

The processing system will be the same; the difference is that EQCover will be offering replacement value while the current scheme offers less.

\section{DISASTER INSURANCE AND COMMERCIAL PROPERTY}

Radical changes are happening to the Earthquake Commission's cover of commercial property. EQC began phasing out its insurance cover of commercial property from 1 January 1993, and its progressive withdrawal from this sector will take 4 years.

The remainder of this section explains how EQC's phase-out of commercial property insurance cover is taking place.

\section{The three options for commercial property}

From 1 January 1993 property owners have had three options in respect of their commercial or industrial property. They have been able to:

- continue to insure their premises with EQC, within the limits of the phase-out, possibly taking top-up insurance from private companies;

buy all their earthquake and other natural disaster insurance from private companies;

do without natural disaster insurance.

\section{The phase-out}

While EQC insurance is available during the phase-out period, the cover is less than $100 \%$, and the amount available is being reduced each year, until no insurance is available at all from EQC for commercial property.
During the phase-out period, EQC insurance on commercial property is optional and limited to:

. $75 \%$ of the specified sum (indemnity value) during the 1993 calendar year

- $50 \%$ of the specified sum (indemnity value) during the 1994 calendar year

$25 \%$ of the specified sum (indemnity value) during the 1995 calendar year

Each stage of the phase-out commences with the policy's inception or renewal within the 1993,1994 or 1995 year.

That means that cover will be available after the policy expires in 1996 or, at the latest, 31 December 1996.

\section{Specified sums, average, indemnity value}

During the phase-out, "specified sums" don't need to be supported by an indemnity valuation certificate but "average" will apply if the specified sum is less than $90 \%$ of the indemnity value at the time of a claim.

Here is an example to explain "average".

\section{EXAMPLE:}

A factory building with a total indemnity value of $\$ 200,000$ has a chimney destroyed in an earthquake. The indemnity value of the chimney is $\$ 10,000$ (indemnity value is explained below). The way the payments would be calculated is as follows:

\section{Without "average"}

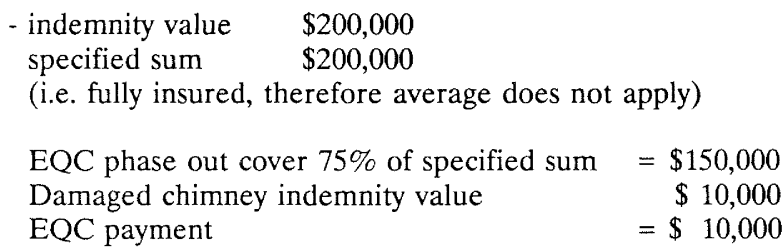

With "average"

indemnity value $\$ 200,000$ specified sum $\$ 100,000$

(i.e. $50 \%$ insured, therefore $50 \%$ average applies)

EQC phase out cover $75 \%$ of specified sum $\quad=\$ 75,000$ Damaged chimney indemnity value $\$ \$ 10,000$ EQC payment $=\$ 10,000 \times 50 \%$ average $\quad=\$ 5,000$

"Average" means that every part of that factory in effect has a $50 \%$ cover. If an earthquake destroyed a factory chimney with an indemnity value of $\$ 10,000$, then the EQC payment on the chimney would be just $\$ 5,000$, or $50 \%$ of the indemnity value.

"Indemnity value" is (in broad terms) the value of an item of property after taking into account the following:

age;

wear and tear;

depreciation (actual and not book value) 
expected useful life.

The indemnity value of a 20-year old factory chimney would be less than for a 10-year old chimney, although the replacement cost of each chimney would be the same.

\section{New provisions of phase-out}

The phase-out from EQC cover of commercial property was started on 1 January 1993 by regulations promulgated the previous year. The Earthquake Commission Act 1993 will take over from the regulations and the previous Act. The 1993 Act changes some details of the phase-out. The most important of the changes affecting commercial property relate to:

Crown-owned commercial property;

motor vehicles and accessories.

There are also significant changes to "special purpose" property, i.e. non-residential property used for religious, charitable, recreational, community, educational, and sporting purposes. Please refer to the background paper on this specific subject.

\section{Crown-owned commercial property}

Crown-owned commercial property is to be treated the same as other commercial property. It was excluded from EQC cover under the old legislation. From 1 January 1994 EQC cover will be available for Crown-owned commercial property, within the limits set by the phase-out.

\section{Motor vehicles and accessories}

The following are no longer to be covered by EQC during commercial property phaseout:

- motor vehicles or any parts of, or accessories to, a motor vehicle;

- trailers, or any parts of, or accessories to, trailers.

\section{Conditions of insurance cover during phase-out}

During the withdrawal EQC intends to leave the conditions of insurance the same as they were under the Earthquake and War Damage Act 1944.

In 1994 the rate will remain at 5 cents for every $\$ 100$ insured, the same rate as has applied since 1945 .

Commercial property owners please note

The information you received last year about the phase-out programme still applies. Apart from the changes indicated in this paper, the phase-out will continue as advised i.e. policies initiated or renewed during calendar year 1994 with EQC will involve cover up to $50 \%$ of indemnity value and during calendar year 1995 up to $25 \%$ of indemnity value.

\section{DISASTER INSURANCE AND "SPECIAL PURPOSE" PROPERTY}

EQC is phasing out its insurance cover of all non-residential property. Nonresidential commercial property was the first to be affected by the withdrawal, with a phase-out of EQC insurance cover beginning on 1 January 1993.
The remaining non-residential property, called "special purpose" property, will be affected by the phase-out from 1 January 1994. "Special purpose" property is nonresidential property used for religious, charitable, recreational, community, educational and sporting purposes.

\section{Reasons for phase-out}

Over the years not enough money has been accumulated to cover the claims which EQC could face after a catastrophic event. By law, the Government is required to meet any shortfall.

In the past, no provision had been made for meeting this shortfall. The cost of this, together with the major welfare costs arising from a disastrous earthquake, would impose a huge strain on the country's finances.

The Government has therefore decided to focus EQC's resources on the prime task of making sure that every family has a roof over their heads after a disaster. EQC cover, after the non-residential property phase-out, is to be restricted to homes and their contents.

\section{Earthquake Commission Act 1993}

When the phase-out of EQC insurance cover of non-residential property began in 1993, the regulations governing the phase-out made an exception for special purpose property, so that $100 \%$ EQC insurance cover was still available during 1993.

However, a consequence of the Earthquake Commission Act 1993 is that special purpose property will be included in the phase-out, starting from 1 January 1994.

Starting from 1 January 1994, special purpose property will be brought into line with commercial property, to form a new combined category covered by the same rules, and called "non-residential property". Phase out of EQC insurance cover for "special purpose"
property

"Special purpose" property which is covered by EQC for full indemnity in a fire insurance policy which is current as at 31 December 1993, will continue to receive full indemnity cover by EQC until the original fire insurance policy upon which EQC cover is based is renewed or cancelled during 1994.

Organisations may, therefore, have up until 31 December 1994, or the earlier date on which their fire insurance policy is renewed, before they lose the full indemnity cover fron EQC.

When either the fire insurance policy is renewed after 1 January 1994, or on 31 December 1994, whichever is the earlier, EQC will offer earthquake and other natural disaster insurance on a reduced basis, for up to but no more than $50 \%$ of the indemnity value.

\section{After 1994: the phase out continues}

That means that special purpose property will, from that point on, be treated on the same basis as other non-residential property whose insurance is renewed during 1994. 
When the policies covering these properties are renewed again in 1995, $25 \%$ indemnity cover will be available from EQC, and cover will phase out entirely during 1996. Organisations owning "special purpose" property should talk to their insurance company or broker about what arrangements to make to best meet this situation.

\section{Government assistance for special purpose buildings after} EQC phase-out

The Associate Minister of Finance, the Hon Simon Upton, has indicated the following:

"It should be noted that although the Crown is not providing an explicit commitment to replace buildings belonging to charitable institutions, this does not necessarily mean that the Government would not be prepared to assist at all in the repair of such buildings after a disaster. The Government would assess on their merits requests for this assistance based on a review of competing needs at the time, bearing in mind the resources available and the Government's fiscal position."

\section{THE EARTHQUAKE COMMISSION: NEW ROLES, NEW STRUCTURE}

The Earthquake Commission, or EQC, is nearly fifty years old. It has served New Zealand well.

However the functions of EQC have changed steadily over the years and are about to change even more fundamentally with the implementation of the Earthquake Commission Act 1993 on 1 January 1994. Accordingly it is changing its structure to carry out its new roles in the most effective way.

EQC is no longer a traditional Government Department, and its former link with the State Insurance Office has long gone. The new roles are even forcing a name change: EQC will no longer be the Earthquake and War Damage Commission, as it will be no longer responsible for war damage claims.

\section{Functions of the EQC}

EQC:

administers the earthquake and natural disaster insurance scheme;

processes and meets claims made by insured parties;

collects premiums from insurance companies;

administers the Disaster Fund.

EQC also encourages and funds research about matters relevant to natural disaster damage, including scientific studies aimed at predicting earthquake, volcanic and related activity, and studying methods of reducing or preventing damage resulting from this activity.

EQC also has an educational role, to provide information on:

the new disaster insurance scheme; and

the prevention and mitigation of damage caused by natural disasters.

The Minister of Finance may ask EQC to carry out other functions.

\section{Getting in shape: the new EOC structure}

The new Earthquake Commission is a Crown Entity, wholly owned by the Government, with a Board of Commissioners. The Minister of Finance has official responsibility for the EQC, but, in practice, this responsibility is usually delegated to one of Associate Ministers of Finance. Currently the Minister responsible for EQC is the Hon Simon Upton.

EQC is controlled by some of the provisions of both the Public Finance Act 1989 and the State Owned Enterprises Act 1986.

EQC is a Body Corporate with perpetual succession and a common seal; in many respects its structure is similar to that of a private company. It is empowered to exercise all the rights, powers and privileges and to incur the liabilities and obligations of a Natural Person. That means it has the power to borrow or to invest money, so as to protect and maintain the Disaster Fund.

\section{EQC Board and Executive}

Membership of the EQC Board is as follows:

- Ian McLean (Chairman)

- Trevor Roberts

- Reg Boorman

- Cliff Collins

- Leicester Stevens

- Kanti Vasan

- Ian Dickson

The General Manager of EQC is David Middleton.

EQC now has a staff of just 12. There is a Finance Manager, a Claims Administrator, inspectors, a Help Desk to assist the public or people in the insurance industry, and the people who carry out the vital functions that keep any office running.

EQC has arrangements with private sector insurance assessors to assist in processing claims, and with private insurance companies for the collection of premium and for certain other administration functions.

\section{The EQCs Disaster Fund}

When homeowners or businesses take out fire insurance with an insurance company, the company includes an EQC levy to cover the cost of earthquake and disaster insurance. These levies are paid into the Disaster Fund. The levies have remained at 5 cents for every $\$ 100$ insured since 1945 , and there are no plans to change this, in spite of the improved cover now offered to homeowners and owners of personal property.

The Fund as at 30 June 1993 was over $\$ 2.3$ billion and, until now, has been invested almost entirely in NZ Government Stock and Treasury Bills.

The Disaster Fund is the fund of money that EQC draws on to pay out on claims for damage caused by natural disasters.

The Commission has been working with the Government to develop an investment policy which better manages the financial risk associated with the fund. Considerable progress has been made. 
How the changes to EQC's structure affect the administration of the Disaster Fund

Up to now all Fund monies have been held in New Zealand, which exposed the Fund to an investment risk associated with the occurrence of a major disaster in New Zealand.

Now about half of the Fund is being invested at the Reserve Bank in especially devised securities linked to part of the Crown's overseas reserves. This move greatly increases the security of the Fund in the event of a major disaster in New Zealand.

As a Body Corporate EQC will be able to take further steps to increase both security and investment returns on the Fund.

\section{Reinsurance}

EQC purchases a substantial amount of reinsurance each year to enhance its ability to pay claims without calling on the government guarantee. With a shortage of capacity in world reinsurance markets, EQC, like other insurers, continues to do much work on the structure and purchase of its reinsurance protection.

\section{REFERENCES}

The Earthquake Commission Act 1993

"A Review of Earthquake Insurance: Public Discussion Paper", New Zealand

Government, 1988

"Public Discussion Paper on Earthquake Insurance", New Zealand Government, 1991

Eiby, Gordon, "Earthquakes in New Zealand"

\section{APPENDIX A}

\section{SOME DISASTER INSURANCE-RELATED STATISTICS}

The following statistical information supplements the above.

\section{EQC'S EARTHQUAKE INSURANCE CLAIMS PAYMENTS FOR SIGNIFICANT EVENTS}

$\begin{array}{lrlrr}\text { Date } & & \text { Location } & \text { Approximate cost } & \text { No. of claims } \\ \text { May } & 1952 & \text { Westport } & \$ 240,000 & \mathrm{n} / \mathrm{a} \\ \text { March } & 1966 & \text { Gisborne } & \$ 200,000 & 1,890 \\ \text { April } & 1966 & \text { Seddon } & \$ 2,430,000 & 1,575 \\ \text { May } & 1968 & \text { Inangahua } & \$ 136,000 & 10,500 \\ \text { November } & 1968 & \text { Wellington } & \$ 150,000 & 2,200 \\ \text { January } & 1972 & \text { Te-Aroha } & \$ 200,000 & 1,300 \\ \text { January } & 1973 & \text { Manawatu/Hawkes Bay/Wellington } & 2,300 \\ \text { April } & 1974 & \text { Dunedin } & \$ 400,000 & 2,767 \\ \text { March } & 1976 & \text { Wairoa } & \$ 100,000 & 829 \\ \text { May } & 1976 & \text { South of South Island } & \$ 200,000 & 450 \\ \text { October } & 1980 & \text { Hawkes Bay } & \$ 527,000 & 2,015 \\ \text { March } & 1987 & \text { Edgecumbe } & \$ 135,816,000 & 5,039 \\ \text { August } & 1989 & \text { South Taranaki Bight } & \$ 100,000 & 2,767 \\ \text { February } & 1990 & \text { Southern Hawkes Bay } & \$ 2,683,000 & 1,267 \\ \text { May } & 1990 & \text { Southern Hawkes Bay } & \$ 7,204,000 & 2,632 \\ \text { January } & 1991 & \text { Westport } & \$ 2,800,000 & 1,997 \\ \text { September } & 1991 & \text { Wanganui } & \$ 2,400,000 & 2,142 \\ \text { May } & 1992 & \text { Marlborough } & \$ 500,000 & 970 \\ \text { June } & 1992 & \text { Whakatane } & \$ 650,000 & 833 \\ \text { August } & 1993 & \text { Gisborne } & \$ 2,500,000 * & 2,100^{*} \\ & & & & \\ & \mathrm{n} / \mathrm{a}=\text { not available } & & *=\text { estimate }\end{array}$


Some examples of actual disaster insurance claims paid compared to the payments that would apply under the new legislation.

Type of damage

Actual payment (under old scheme)

Chimney

$\$ 2,200.00$

$\$ 2,000.00$

$\$ 701.00$

$\$ 2,925.00$

$\$ 6,824.00$

$\$ 2,750.00$

$\$ 2,155.00$

$\$ 1,264.00$

Ornaments, hot water cylinder, interior walls

Chimney

Chimney

Chimney
Would pay (under new scheme)

EDGECUMBE EARTHQUAKE - 2 MARCH 1987

$\begin{array}{llc}\text { Claims Payments } & \text { Total Cost } & \text { No. of Claims } \\ \begin{array}{lll}\text { Domestic } \\ \text { Commercial }\end{array} & \$ 18,949,445(14.67 \%) & 4,352(86.36 \%) \\ & \$ 110,192,579(85.33 \%) & 87(13.64 \%) \\ \text { Fees } & \$ 129,142,024 & \overline{5,039} \\ & \$ 6,673,494 & \\ \text { TOTAL } & \$ 135,815,518 & \end{array}$

ANNUAL DEVELOPMENT OF THE DISASTER INSURANCE FUND

(Premiums plus investment income less claims, EQC's expenses, reinsurance premiums incurred, and Crown fees.)

$\begin{array}{lr}1983 / 84 & 880,521,000 \\ 1984 / 85 & 1,068,770,000 \\ 1985 / 86 & 1,317,003,000 \\ 1986 / 87 & 1,624,825,000 \\ 1987 / 88 & 1,873,921,000 \\ 1988 / 89 & 1,963,557,000 \\ 1989 / 90 & 2,017,173,000 \\ 1990 / 91 & 2,139,341,000 \\ 1991 / 92 & 2,232,522,000 \\ 1992 / 93 & 2,330,000,000 \text { (Approximate) } \\ 1993 / 94(30 / 6 / 94) & 2,400,000,000 \text { (Forecast) }\end{array}$

